\title{
BŪSIMŲ PAREIGŪNŲ - LTU STUDENTŲ — POŽIŪRIS İ FIZINĖS SVEIKATOS BŪKLE்S KONTROLĘ IR VALDYMĄ
}

\author{
Algirdas Muliarčikas ${ }^{1}$, Aurelija Morkūnienè1, Edmundas Štarevičius ${ }^{1}$, Vaidas Mickevičius ${ }^{2}$ \\ Mykolo Romerio universitetas ${ }^{1}$, Kauno technikos kolegija², Kaunas, Lietuva
}

\begin{abstract}
Algirdas Muliarčikas. Docentas socialinių mokslu daktaras. Mykolo Romerio universiteto Kauno policijos fakulteto Specialaus fizinio rengimo katedros vedejjas. Mokslinių tyrimų kryptis - sociopedagoginių, psichologinių ir fizinių ypatybių lavinimo valdymo aspektai asmenybės ir specialisto ugdymo procese.
\end{abstract}

\section{SANTRAUKA}

Tyrimo tikslas - išsiaiškinti bei palyginti 2002 ir 2003 m. istojusiuju z Lietuvos teisés universiteto Kauno policijos fakulteta požiūrí i sveikatos büklès kontrole, jos valdymo aspektus.

Straipsnyje pateikiami studentu, 2002 ir 2003 m. istojusiu i Lietuvos teisès universiteto Kauno policijos fakulteta (LTU $K P F)$, anketinès apklausos duomenys, parodantys ju žinias bei subjektyviq nuomonę apie sveikatos bükle, jos kontrolès ir valdymo büdus. Anonimiškai apklausti pirmo kurso studentai (2002 m. - 219, $2003 \mathrm{~m}$. - 127). Anketa aprobuota. Atliktas bandomasis tyrimas, nustatytas anketos stabilumas. Straipsnyje pateikiami duomenys apie studentu požiūri i fizinès sveikatos būklę ir jos valdymo ypatumus - išanalizuoti, sugrupuoti aštuoniolikos klausimu 16555 atsakymai. Taip pat buvo palyginti darančiuju mankšta (215), nesimankštinančiuju (131) atsakymai ir duomenys pagal lyti (141 moters ir 205 vyru).

Dauguma apklaustu studentu rūpinosi savo sveikata (90,2\%). Lyginant su 2002-aisiais, didesnès 2003 m. istojusiu studentu dalies subjektyvi sveikatos büklè patenkinama $(p<0,05)$, mažesnès - gera $(p<0,01)$. Didesnè dalis vyru $(p<0,05)$, lyginant su moterimis ir sportuojančiuju $(p<0,001)$ su nesportuojančiaisiais, savo sveikata ivertino kaip gerq. Didesne dalis studentu informacija apie ivairius fizinès sveikatos gerinimo aspektus norètu gauti iš televizijos $(47,4 \%)$, statistiškai patikimai mažesnè dalis $(37,3 \%, p<0,01)$ - per paskaitas, iš periodinès spaudos $(22,3 \%)$ ar specialisto konsultacijos metu $(25,1 \%)$. Mažesnè visu respondentu dalis $(45,7 \%, p<0,05)$ teigé, kad bendrojo lavinimo mokykloje igijo žiniu apie kūno kultūros poveiki sveikatai. Dauguma apklaustuju $(60,9 \%, p<0,001)$ teigè, kad doméjosi ir domisi informacija apie fiziniu pratimu poveiki sveikatai. 46,9\% $(p<0,001)$ respondentu teigè, kad tokios literatūros yra pakankamai, 20\% — kad ne, o 30,2\% — nesidomejo ja.

Savo fizinès sveikatos būklę pagal pulso dažnị kontroliavo tik 21,1\% respondentu ( $<<0,001), 68,8 \%$ - nekontroliavo, $9,2 \%(p<0,001)$ net nemoka jo skaičiuoti. 2003 m. pirmakursiu $(p<0,01)$, nesusipažinusiu su pulso dažnio skaičiavimo metodika, buvo daugiau nei

2002-aisiais. LTU KPF studentai turi teisinga samprata apie fizinès sveikatos gerinimo būdus. Tačiau palyginti maža respondentu dalis turi informacijos apie elementariausius žmogaus büklès kontrolès bei fizinio aktyvumo proceso valdymo metodus ir, bègant metams, ta dalis mažèja.

Raktažodžiai: fizinè sveikata, žinios apie fiziologinius rodiklius, organizmo būklès kontrolè, laisvalaikio fizinio aktyvumo proceso valdymo aspektai.

\section{IVADAS}

$\mathrm{K}$ onkrečioje veikloje pageidaujant gauti pažangių rezultatų, rekomenduojama vadovautis bendriausiais strateginio valdymo principais. Nepaisant to, ar siekiama vadovavimo, ar asmeninio tobulëjimo, tikslinè orientacija bei etapinès ir einamosios kontrolès (tyrimo) funkcijos yra neatskiriamos sèkmingo strateginio planavimo ir valdymo proceso sudedamosios dalys (Vasiliauskas, 2002; Skernevičius ir kt., 2004). Dažniausiai proceso valdymo sèkmę lemia turima informacija apie poveikio metodus ir dèl jų panaudojimo îvykstančius pokyčius.
Norint kokybiškai atlikti vieną iš pagrindinių veiklos — viešosios tvarkos bei piliečiu saugumo garantavimo - funkcijų, esamiems ir būsimiesiems pareigūnams būtinas įvairiapusis profesinis teorinis ir praktinis pasirengimas. Ivairūs gebèjimai, igytos žinios ir galimybè ekstrapoliuoti jomis, daugiausia lemia intelekto, kultūros lygi ir nuosekliai ugdo pareigūną kaip specialistą, sudaro prielaidas darbo efektyvumui gerinti (Šakočius, 2000; Kalesnykas, 2002, 2003; Gage, Berliner, 1994). Pareigūnų kasdienio darbo efektyvumas, garantuojant viešają tvarką, teikiant pagalbą ir 
skubias paslaugas skirtingų visuomenès sluoksnių gyventojams, pasiekiamas ne tik išsamių žinių apie ivvairias gyvenimo sritis, bet ir geros fizinès sveikatos, puikaus vientiso specialaus fiziniofunkcinio-psichinio parengtumo dèka. Toks parengtumas pasiekiamas ir palaikomas tik nenutrūkstamai visapusiškai lavinantis, t. y. lavinantis visą gyvenimą. Kalbinio, loginio-matematinio, kūniško estetinio, vidinio asmeniškojo ir tarpasmeninio intelekto lavinimas (Gardner, Hatch, 1989) akivaizdžiai veikia šio lavinimosi proceso rezultatyvumą. Norint palaikyti reikiamą fizinès sveikatos būsenos - optimalaus žmogaus kūno funkcionavimo (Sporto terminu žodynas, 2002) lygi, būtinos žinios apie sveiko, aktyvaus gyvenimo būdo, žmogaus psichikos ir fiziologinius ypatumus, jų kontrolès ir valdymo priemones bei metodus (Poderys, 2000; Muliarčikas, 2003 a). Subjektyvus fizinès sveikatos vertinimas, fiziologinių rodiklių kitimo kontrolè, aktyvaus gyvenimo būdo pasirinkimas ir neigiamų ipročių išvengimas - vienos iš aktualesnių sąlygų, lemiančių pozityvų sveikatos tausojimo ir reikalavimus atitinkantị fizinio pasirengimo procesą (Goštautas, Šeibokaitė, 2003; Petkevičienè ir kt., 2002; Poderys, 2000).

Taigi kokios istojusiuju i Kauno policijos fakultetą - būsimuju pareigūnų - požiūrio i savo fizinę sveikatą, jos būsenos kontrolę, valdymą tendencijos ir kiek jie turi žinių, kurios reikšmingai lems jų tolesni intelekto ugdymo procesą, mėginome panagrinèti šiame straipsnyje.

Tyrimo tikslas - išsiaiškinti ir palyginti 2002 ir 2003 m. įstojusiuju i Lietuvos teisès universiteto Kauno policijos fakultetą požiūrị i fizinès sveikatos būsenos kontrolę, valdymo aspektus.

\section{TYRIMO METODAI IR ORGANIZAVIMAS}

Anketinès apklausos būdu apklausti LTU (2004 m. gruodžio mèn. Lietuvos teisès universitetas pavadintas Mykolo Romerio universitetu) Kauno policijos fakulteto pirmo kurso studentai (2002 m. (LTU 02) - 219, 2003 m. (LTU 03) 127). Anketą sudarė 40 klausimų, santykiškai suskirstytų pagal tris aspektus: požiūrị i savo sveikatą, fizini aktyvumą, būklès kontrolę. Anketa aprobuota - buvo atliktas bandomasis tyrimas, nustatytas anketos stabilumas (Tidikis, 2003). Straipsnyje pateikiami duomenys tik apie studentu požiūrị i fizinès sveikatos būklę ir jos valdymo ypatumus - išanalizuoti ir sugrupuoti 18 klausimu 16555 atsakymai, kurie dar suskirstyti pagal darančiuosius mankštą (215), nesimankštinančiuosius (131) ir pagal lyti (141 moteris ir 205 vyrai). Paveiksluose pateiktos atsakymų vidurkio reikšmès (LTU).

Grupių atsakymų variantu skirtumo patikimumui nustatyti naudojome $\chi^{2}$ (chi kvadrato) rodikli (Čekanavičius, Murauskas, 2001).

\section{REZULTATAI}

Beveik visi apklausti Kauno policijos fakulteto studentai teige, kad rūpinasi $(90,2 \%)$ savo sveikata. Šiuo požiūriu 2002 (89\%) ir 2003 $(91,3 \%)$ metais įstojusiujų atsakymai statistiškai panašūs $(p>0,05)$. Daugiau apklaustų vyrų nei moteru $(\mathrm{p}<0,05)$ ir sportuojančių studentų $(\mathrm{p}<0,001)$ teigè, kad rūpinasi savo sveikata. Savo sveikatą didesnè visų apklaustų studentų dalis $(54 \%-\mathrm{p}<0,001)$ vertino patenkinamai, likusieji - gerai $(39,9 \%)$ ir nepatenkinamai $-4,3 \%$. Mažesnè dalis apklaustų moteru $(p<0,05)$ nei vyrų ir nesportuojančiujų ( $p<0,001)$ nei sportuojančių studentų savo sveikatos būklę vertino kaip gerą.

Lyginant su 2002 m., didesnès 2003-aisiais ístojusių studentų dalies subjektyvi sveikatos būklè patenkinama $(\mathrm{p}<0,05)$, mažesnès - gera $(\mathrm{p}<0,01)$ (1 pav.). Didelè respondentų dalis savo sveikatą tikrino $1-2$ kartus per metus $(66,7 \%$, $\mathrm{p}<0,001), 18,9 \%$ - rečiau nei kartą, o $13,5 \%$ dažniau nei 3 kartus per metus ( 2 pav.). Didesnè dalis pirmakursių $(\mathrm{p}<0,01)$ pas gydytojus lankèsi $1-2$ kartus per metus.

$95,2 \%$ respondentu $(92,7 \%$ istojusiu $2002 \mathrm{~m}$. ir $97,6 \%-2003$ m., p > 0,05) teigè, kad mankšta padeda stiprinti sveikatą. Taip pat dauguma apklaustuju teigè $(60,9 \%, \mathrm{p}<0,001)$, kad doméjosi ir domisi informacija apie fiziniu pratimu poveiki sveikatai. 46,9\% $(\mathrm{p}<0,001)$ respondentų manè, $\mathrm{kad}$ tokios literatūros yra pakankamai, $20 \%$ nepakanka, o 30,2\% nesidomejo ja (3 pav.). Skirtingais metais istojusiujų nuomonès buvo panašios $(\mathrm{p}>0,05)$.

Didesnè dalis studentų informaciją apie įvairius fizinès sveikatos gerinimo aspektus norètu gauti iš televizijos $(47,4 \%)$, statistiškai patikimai mažesnè $(37,3 \%, p<0,01)$ - per paskaitas, iš periodinès spaudos $(22,3 \%)$ ar specialisto konsultaciju metu $(25,1 \%)$ (4 pav.).

Palyginus 2002 ir 2003 m. (atitinkamai 51,8 ir 


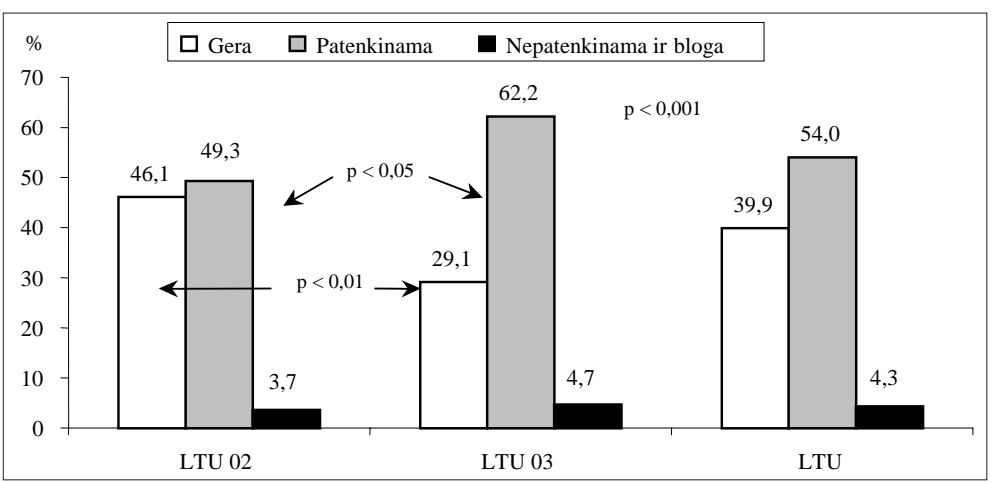

1 pav. Atsakymai į klausimą „Kaip vertinate savo fizinès sveikatos būklę?“"

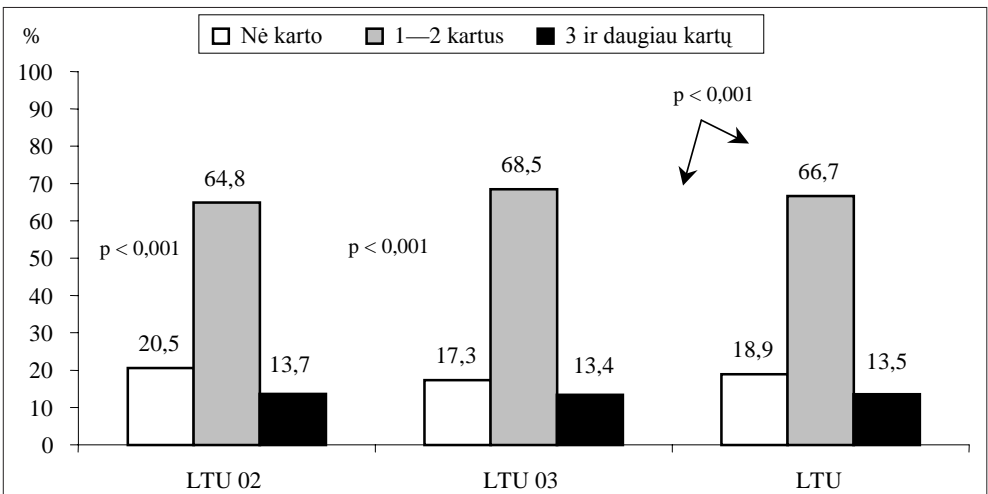

2 pav. Atsakymai i klausimą „Ar dažnai lankotès pas gydytojus?"
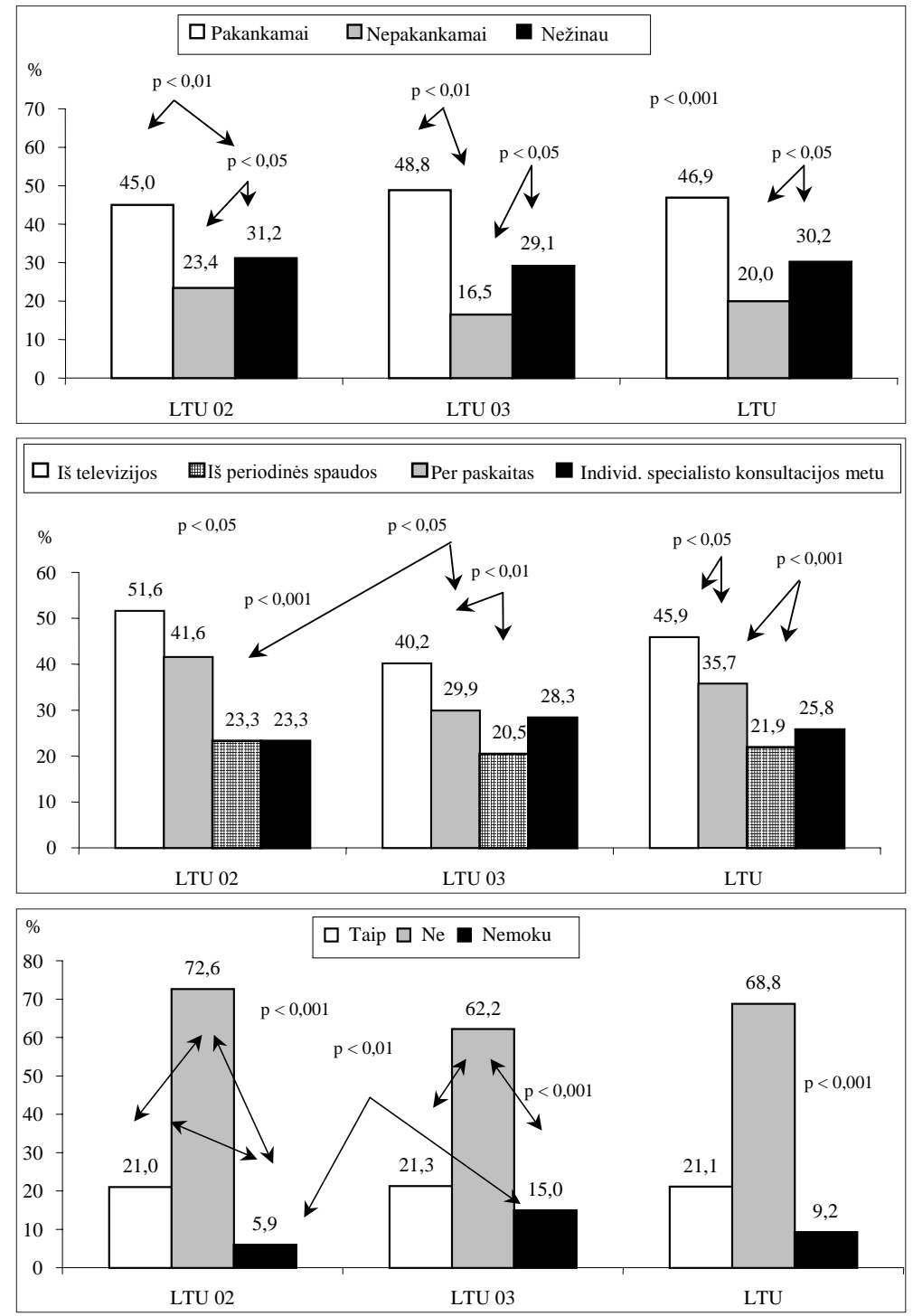

3 pav. Atsakymai ị klausimą „Ar yra literatūros apie fizinių pratimų atlikimą, jų poveikị sveikatai?“‘

4 pav. Atsakymai ị klausimą, ,Kokiu keliu gaunate (norètumète gauti) informaciją apie fizinès sveikatos gerinimo būdus?“‘

5 pav. Atsakymai ị klausimą „Ar Jūs skaičiuojate savo pulso dažnị?“" 
$42,4 \%$ vyru, 51,3 ir $37,7 \%$ moteru $(\mathrm{p}<0,05), 48,4$ ir $30,5 \%$ sportuojančiujų $(\mathrm{p}<0,01)$ pirmakursių atsakymus paaiškejjo, kad tokią informaciją gauti per paskaitas labiau pageidavo įstojusieji ankstesniais metais. $39,3 \% 2003 \mathrm{~m}$. įstojusių moteru šiuo požiūriu labiau vertino specialisto konsultacijas, $2002 \mathrm{~m}$. įstojusiuju $-15 \%(\mathrm{p}<0,001)$. Mažesnè visų respondentų dalis $(45,7 \%, \mathrm{p}<0,05)$ teigè, kad vidurinio lavinimo mokykloje igijo žinių apie kūno kultūros poveikị sveikatai.

Savo fizinès sveikatos būklę pagal pulso dažni kontroliavo tik $21,1 \%$ respondentu $(\mathrm{p}<0,001)$, $68,8 \%$ - nekontroliavo, $9,2 \%(\mathrm{p}<0,001)$ net nemokejo jo nustatyti (5 pav.). 61,3\% visu apklaustujų $(\mathrm{p}<0,001)$ nežinojo savo pulso dažnio. Daugiau 2003 nei 2002 metų pirmakursiu $(\mathrm{p}<0,01)$ nemokejo matuoti savo pulso dažnio (5 pav.). Kur kas daugiau studentų, pradejjusių studijuoti $2003 \mathrm{~m}$. (68,9\%), lyginant su 2002aisiais $(48 \%)(\mathrm{p}<0,01)$, nežinojo savo pulso dažnio reikšmių.

Studentų nuomonè apie kraujospūdi, kaip apie žmogaus sveikatos būklès rodiklị, pasiskirstẻ į tris statistiškai patikimai $(\mathrm{p}<0,001)$ skirtingas grupes. Dauguma apklaustujų (64,7\%) manè, kad kraujospūdis parodo žmogaus sveikatos būklę, 24,6\% 6 pav. Atsakymai ị klausimą „Kokius 3 būdus rink-
tumètès fizinei sveikatai gerinti?““

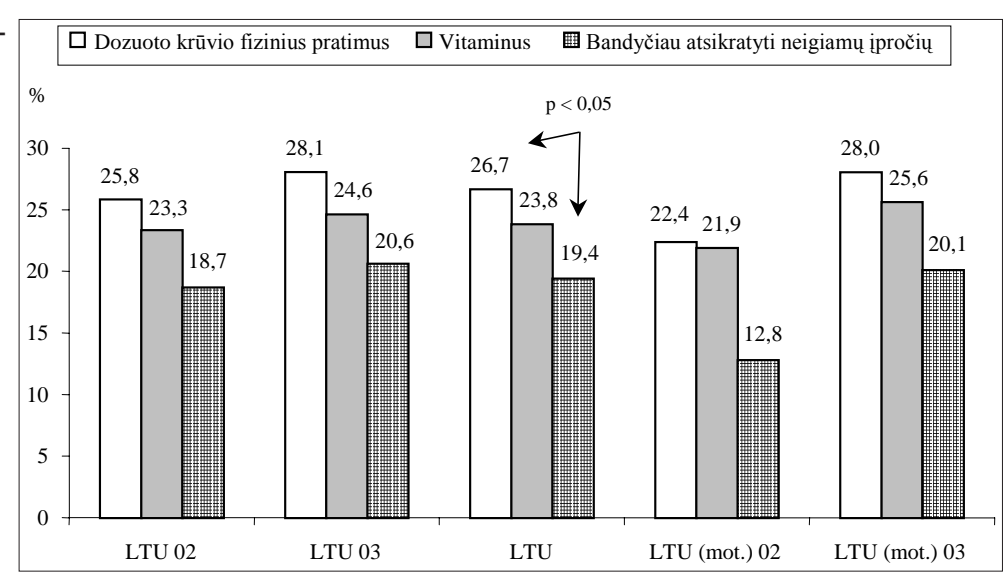

7 pav. Atsakymai ị teiginị „Dieną būnate darbingas, jei ryte..."

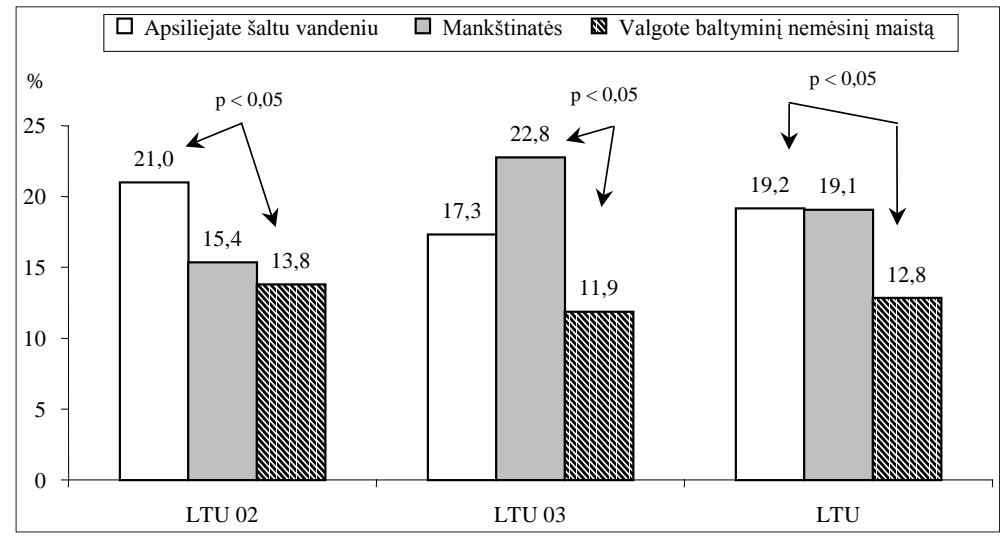

8 pav. Atsakymai ị klausimą, ,Kas, Jūsų manymu, turètų pradèti vykdyti Lietuvos žmonių fizinès sveikatos gerinimo procesą?“

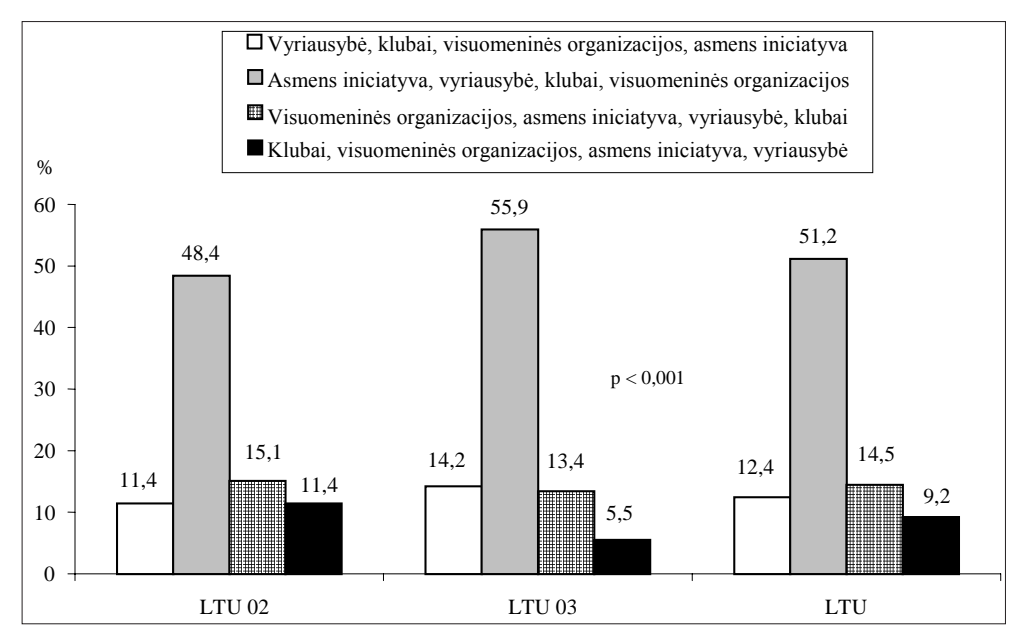


tikslaus atsakymo nežinojo, o 7,2\% teigè, kad neparodo. $62,6 \%$ visų respondentų $(\mathrm{p}<0,001)$ nèra matavę kraujospūdžio. 35,7\% studentų teigè, kad kraujospūdi matuoja (13,3\% - kartą per metus, $16,5 \%$ - kartą per mènesị, kiti - dažniau). 55\% visų respondentų nežinojo savo kraujospūdžio reikšmiu ( $\mathrm{p}<0,001)$. 66,1\% respondentų nesidomèjo asmeninio kraujospūdžio dydžiu, nes gerai jautėsi, o kiti teigè neturintys sąlygu ji pamatuoti.

Norédami atsikratyti antsvorio, 52,8\% studentų didžiausią dèmesí, lyginant su kitomis priemonèmis $(\mathrm{p}<0,001)$, skirtų fiziniam aktyvumui, $36,7 \%$ - mitybos derinimui, o 3,9\% - ji mažintų dažniau eidami i pirtị $(p<0,001)$. Studentų many$\mathrm{mu}$, jų sveikatos gerejimo procesą teigiamiausiai veikia dozuoto krūvio fiziniai pratimai $(26,7 \%)$, vitaminų vartojimas $(23,8 \%)$ ir neigiamų ipročių atsikratymas $(19,4 \%$, lyginant su fiziniais pratimais - $\mathrm{p}<0,05)$. Tendencingai daugiau $(\mathrm{p}>0,05) 2003 \mathrm{~m}$. įstojusių studenčių teigè, kad būtina atsikratyti neigiamu ipročiu (6 pav.).

Respondentai teigè ( 7 pav.), kad gerą darbingumą dieną lemia rytinis apsiliejimas šaltu vandeniu $(19,2 \%$,) ir mankšta $(19,1 \%)$, lyginant su kitomis priemonemis. Trečiu (2002 m.) ir ketvirtu (2003 m.) pagal reikšmingumą studentai rinkosi baltyminio nemėsinio maisto vartojimą $(12,8 \%)$. 2003 metu pirmakursiai (moterys ir visi sportuojantieji), vertindami pagal svarbą veiksnius, lemiančius dienos darbingumą, trečiu įvardijo $(p<0,05)$ visaverti miegą $(2002 \mathrm{~m}$. - šeštu).

Atsakydami į klausimą, „Kas, Jūsų manymu, turètu pradèti vykdyti Lietuvos žmoniu fizinès sveikatos gerinimo procesą?", daugiau kaip pusè visų studentu $(51,2 \%)$ pasirinko teigini, kad sveikata turi rūpintis pats žmogus, kuriam šiuo požiūriu visokeriopai pagelbètu vyriausybè, klubai ir visuomeninès organizacijos. Kiti atsakymų variantai ( 8 pav.) priimtini buvo atitinkamai statistiškai patikimai $(p<0,001)$ mažesnei respondentų daliai.

\section{REZULTATŲ APTARIMAS}

Beveik visi apklausti Lietuvos teisès universiteto (šiuo metu - Mykolo Romerio universiteto) Kauno policijos fakulteto studentai - būsimieji pareigūnai, jų manymu, rūpinasi arba yra nusiteikę rūpintis savo sveikata. Vidutiniai rodikliai, nusakantys 2002 ir 2003 m. LTU pirmakursiu sveikatos būklę, pagal vertinimo kategorijas ,gera“ ir „bloga“ daug blogesnè nei 2000-aisiais apklaustų šešių Kauno universitetų pirmakursių (Petrauskas, 2004).

Respondentų subjektyvus sveikatos vertinimas, bėgant metams, reikšmingai blogeja. Situacija nèra teigiama, nes studentų sveikatos būklè studiju proceso metu ir taip turi tendenciją blogèti (Armonienè, 1994). A. Zaborskio (2001) teigimu, Lietuvos jaunimas, lyginant su kitu Pabaltijo šalių, juo labiau su kitu pasaulio šalių bendraamžiais, savo sveikatos būklę linkęs vertinti negatyviau. Apibendrinant teiginius apie subjektyvu studentų sveikatos būklès vertinimą, reikètų atkreipti dèmesi i tai, kad savijautos ir sveikatos būklès vertinimą lemia daug veiksnių. Vienas iš jų - lankymasis pas gydytojus. Nors, lyginant su Lietuvos gyventojų apklausos duomenimis (Grabauskas ir kt., 1997), mažesnè mūsų apklaustu studentų dalis apsilankydavo pas gydytojus rečiau nei kartą ir didesnè $-1-2$ kartus per metus. Sveikatos būklę galima vertinti pagal daugelị sudedamujų, viena iš jų — tyrimų rodikliai, leidžiantys daryti objektyvias išvadas. Prieš studijas būsimujų studentų sveikata buvo nuodugniai ištirta medicinos įstaigoje ir tik tiems, kurių sveikatos būklè atitiko apibrèžtus reikalavimus, buvo išduotos ši faktą patvirtinančios pažymos. Tačiau tikètina, kad bėgant metams ar esant tam tikroms sąlygoms atsiranda tendencija neigiamiau vertinti savo sveikatos būklę.

Patikimai didesnè respondentų dalis teigia, kad yra pakankamai literatūros apie fizinių pratimų atlikimą ir poveikị sveikatai. Atsižvelgiant ị tai galima teigti, kad beveik pusė apklaustuju gerai vertina savo žinias. Palyginus su kitu autoriu duomenimis (Tamošauskas, 2000), didesnè (apie $15 \%)$ tirtų studentų dalis teige turintys žinių apie fizinio aktyvumo metodikos ypatumus.

Informaciją apie fizinès sveikatos gerinimo būdus didžioji respondentų dalis (apie 45\%) norètu gauti iš televizijos. Antru informacijos šaltiniu ivardytos paskaitos. Išsamesnès informacijos apie paskaitų ir pratybų vertinimą mes nerinkome. P. Tamošausko (2000) teigimu, nemažai apklaustų Lietuvos universitetų studentu (vidutiniškai apie $32 \%$ ) pageidauja teorinio rengimo dalies kūno kultūros dalyko programoje ir įvairiapusiško, nemonotoniško, tobulèti skatinančio pratybu turinio. Studentai vis labiau vertina ir specialisto konsultacijas. Lyginant su P. Tamošausko (2000) pateiktais duomenimis, net $30 \%$ daugiau LTU KPF 2003 metu pirmakursiu (ypač merginų) rūpimais klausimais konsultuotųsi su specialistais. 
Deja, respondentų žinios apie prieinamiausius ir reikšmingus organizmo būklès rodiklius nèra pakankamos. Tik penktadalis respondentų kontroliuoja savo būklę skaičiuodami pulso tvinksnius, o apie pusė nežino jo reikšmių. Panaši apklausoje dalyvavusių studentų dalis nežino savo kraujospūdžio reikšmių. Daugiau kaip pusè apklaustų pirmakursių nežinojo nei savo pulso, nei kraujospūdžio reikšmių, o trečdalis manè, kad šie rodikliai nerodo sveikatos būklès. Nors 2002 ir $2003 \mathrm{~m}$. pirmakursiu atsakymų variantai i klausimą, „Ar skaičiuojate savo pulso dažnį?“, statistinio patikimumo požiūriu buvo panašus, bet patikimai didesnè $2003 \mathrm{~m}$. įstojusiuju dalis teigè, kad nežino savo pulso reikšmių. Tokia situacija, manome, apriboja studentų galimybę laisvalaikiu savarankiškai mankštintis nedarant neigiamo poveikio sveikatai. Pulso ir kraujospūdžio rodiklių dydis, kitimas fizinio krūvio ir atsigavimo laikotarpiu objektyviai rodo besimankštinančio asmens būklę (Forjaz et al., 2004; Gall et al., 2004; Skernevičius ir kt., 2004; Poderys, 2000). Esamos situacijos paradoksalumas (gal net problemiškumas) atsiranda dèl to, kad studentai fizini aktyvumą įvardija ir galbūt naudoja kaip vieną pagrindinių priemonių, efektyviausiai veikiančių kūno masès normalizavimą (antsvorio mažinimą), sveikatos gerinimą ir eilinès jų dienos darbingumą.

Neigiamu ipročiu atsikratymas, konkrečiai rūkymo, LTU KPF studentų, o ypač merginų, nuomone, yra vienas iš trijų būdų, labiausiai veikiančiu sveikatos gerinimą. Bègant metams, ši problema darosi vis aktualesnè. Deja, tokios tendencijos pastebimos ir kitose Kauno aukštosiose mokyklose (Varatinskienè, 1993). Rūkančiu jaunuolių daugèja, be to, stresiniais laikotarpiais (baigiant mokyklą ir pan.) daugiau vaikinų, turinčių neigiamu ipročių, deklaruoja apie pablogèjusią savo sveikatos būklę (Goštautas, Šeibokaitè, 2003). Kita pakankamai aktuali sąlyga, lemianti ne tik LTU studijuojančių, bet ir kitu universitetų studenčių (Tamošauskas, 2000; Grinienè, 2003) savijautą ir dienos darbingumą, visaverčio miego trūkumas.

Dauguma apklaustų LTU KPF pirmakursių turi prielaidas sveiko, fiziškai aktyvaus gyvenimo būdo nuostatoms ugdytis. Jų nuomone, asmeninè iniciatyva - viena pagrindinių sąlygų, lemiančiu rezultatyvią sveikatinimo proceso eigą, tačiau nepakankamos žinios ir praktinių igūdžiu stoka riboja fizinès saviugdos procesą, jo kontrolę ir valdymą. Tokios aplinkybès nemaža dalimi skatina studentų pasyvaus poilsio populiarumą (Tamošauskas, 2000; Muliarčikas, 2003 b).

\section{IŠVADOS}

1. Absoliuti dauguma visu LTU KPF 2002 ir $2003 \mathrm{~m}$. pirmakursių, didesnè dalis vyrų, lyginant su moterimis ir sportuojančiujų su nesportuojančiaisiais, teigia, kad rūpinasi savo sveikata. Patikimai didesnè $2003 \mathrm{~m}$. pirmakursių dalis, lyginant su $2002 \mathrm{~m}$. įstojusiujų, savo sveikatą vertina „patenkinamai“, mažesnè „gerai“. Dauguma respondentų nepakankamai kontroliuoja savo organizmo būklę ir jos kitimą: penktadalis pas gydytojus lankosi rečiau nei kartą per metus ir trys penktadaliai - tik karta ar du.

2. Skirtingų studijų metų pirmakursių nuomonè apie televiziją, kaip pagrindini informacijos apie fizinių pratimų poveiki sveikatai gavimo šaltini, sutampa. Statistiškai patikimai didesnè $2002 \mathrm{~m}$. pirmakursių dalis (pagal vyrų, moterų ir sportuojančiujų grupes), lyginant su $2003 \mathrm{~m}$. studentais, pageidautu daugiau informacijos gauti paskaitų metu. 2003 metu pirmakursès akcentavo šios srities specialisto konsultaciju svarbą $(\mathrm{p}<0,001)$.

3. Tik $45 \%$ visų respondentų teige, kad vidurinio lavinimo įstaigoje igijo žinių apie kūno kultūros poveiki sveikatai. Apie tris penktadalius apklaustų studentų nežinojo savo pulso dažnio $(61,3 \%)$ ir kraujospūdžio (55\%) reikšmių. Statistiškai patikimai didesne $2003 \mathrm{~m}$. pirmakursiu dalis nežinojo savo pulso reikšmių ir nemokejjo jo skaičiuoti.

4. Palyginus 2002 ir $2003 \mathrm{~m}$. pirmakursiu apklausos rezultatus, galima teigti, kad vèlesniais metais i LTU KPF ịstojo:

- mažesnè dalis subjektyviai gerai vertinančių savo sveikatos būklę ir turinčiujų pakankamai žinių apie ją nusakančius rodiklius;

- mažiau nusiteikusių gauti informacijos apie kūno kultūros poveikị sveikatai paskaitų metu;

- mažiau igijusių konkrečios informacijos apie fizinio ugdymo proceso kontrolès vykdymo ypatumus vidurinio lavinimo istaigose, bet turinčiu pozityvias prielaidas sveiko, aktyvaus gyvenimo būdo nuostatų ugdymui, t. y. akcentuojančių specialistų konsultacijų, neigiamų ipročiu atsikratymo, fizinio aktyvumo, gyvenimo režimo - maitinimosi ir poilsio, asmeninès iniciatyvos veiksnių svarbą siekiant tikslo. 


\title{
LITERATŪRA
}

Armonienè, J. (1994). Kūno kultūra ir studenčių sveikata. Kūno kultūros problemos Lietuvos aukštojoje mokykloje (p. 18). Kaunas: Ritmas.

Čekanavičius, V., Murauskas, G. (2001). Statistika ir jos taikymai. Vilnius: TEV.

Forjaz, C. L. M., Cardoso, C. G., Rezk, C. C. et al. (2004). Postexercise hypotension and hemodynamics: The role of exercise intensity. The Journal of Sport Medicine and Physical Fitness, 44 (1), 54-61.

Gage, N. L., Berliner, D. C. (1994). Pedagoginè psichologija. Vilnius: Alma litera.

Gall, B., Parkhouse, W., Goodman, D. (2004). Heart Rate Variability of Recently Concussed Athletes at Rest and Exercise. Medicine and Science in Sport and Exercise, 36 (8) 1269 - 1274.

Gardner, H., Hatch, T. (1989). Multiple intelligences go to school: Educational implications of the theory of multiple intelligencies. Educational Researcher, 18 (8), 4-10.

Goštautas, A., Šeibokaitè, L. (2003). Moksleivių narkotinių medžiagų vartojimo, priklausančio nuo savo sveikatos vertinimo, kitimas amžiaus tarpsniais. Socialinis darbas, 2 (4), 103-110.

Grabauskas, V., Klumbienè, J., Petkevičienè, J. ir kt. (1997). Suaugusiu Lietuvos žmoniu gyvensenos tyrimas, 1994. Kansanterveyslaitos: National Public Health Institute, Finland, 75.

Grinienè, E. (2003). Lietuvos kūno kultūros akademijos studentų laikas, skiriamas studijoms ir gyvenimiškiems poreikiams tenkinti. Ugdymas. Küno kultūra. Sportas, 3 (48), 25-32.

Kalesnykas, R. (2002). Policijos funkciju igyvendinimo efektyvumas: viešujų ir privačiu interesų derinimo problema. Jurisprudencija. Visuomenès saugumas ir policijos mokslai, 24 (16), 43-56.

Kalesnykas, R. (2002). Policijos pareigūnai kai kuriose Europos valstybėse. Jurisprudencija. Visuomeness saugumas ir policijos mokslai, 48 (40), 65-78.
Muliarčikas, A. (2003 a). Kauno miesto gyventoju požiūrio ì sveikatą ir fizini aktyvumą tendencijų aspektai. Visuomenés sveikata, 4 (23), 44-49.

Muliarčikas, A. (2003 b). Kauno studentų laisvalaikio fizinis aktyvumas ir ji lemiantys veiksniai. Ugdymas. Küno kultūra. Sportas, 5 (50), 44-51

Petkevičienè, J., Kardelis, K., Misevičienè, I., Petrauskas, D. (2002). Kauno aukštujų mokyklų studentų fizinio aktyvumo, žalingu ipročiu ir studiju krypties sasaja. Ugdymas. Küno kultūra. Sportas, 4 (45), 77-84.

Petrauskas, D. (2004). Kauno universitetu studentu subjektyvios sveikatos, savijautos ir gyvensenos sqsaju vertinimas: daktaro disertacija. Kaunas.

Poderys, J. (2000). Asmens sveikatos ugdymas. Kaunas: Kauno medicinos universitetas.

Skernevičius, J., Raslanas, A., Dadelienè, R. (2004). Sporto mokslo metodologija. Vilnius: Lietuvos sporto informacijos centras.

Sporto terminužodynas. (2002). Parengè S. Stonkus. T. 1. Kaunas: Aušra.

Šakočius, A. (2000). Policija valstybėje ir visuomenèje: nuo distinktyviai iki racionaliai pragmatinio požiūrio i policijos paslaugą. Jurisprudencija. Visuomenès saugumas ir policijos mokslai, 15 (7), 167-172.

Tamošauskas, P. (2000). Humanistiškai orientuotas studentu fizinis ugdymas. Vilnius: Technika.

Tidikis, R. (2003). Socialiniu mokslu tyrimu metodologija. Kaunas: Aušra.

Varatinskienè, R. (1993). Kauno aukštuju mokyklu studentu gyvensenos ypatybès ir sveikata: med. $m$. dr. disertacija. Kaunas: Kauno medicinos akademija.

Vasiliauskas, A. (2002). Strateginis valdymas. Vilnius: Enciklopedija.

Zaborskis, A., Makari, J. (2001). Lietuvos moksleiviu gyvensena: raida 1994-1998 metais ir vertinimas tarptautiniu požiūriu. Panevėžys: E. Vaičekausko leidykla.

\section{ATTITUDE OF FUTURE OFFICERS (STUDENTS OF THE LITHUANIAN LAW UNIVERSITY) TO CONTROL AND MANAGEMENT OF PHYSICAL FITNESS}

\author{
Algirdas Muliarčikas ${ }^{1}$, Aurelija Morkūnienè ${ }^{1}$, Edmundas Štarevičius ${ }^{1}$, Vaidas Mickevičius ${ }^{2}$ \\ Mykolas Romeris University ${ }^{1}$, Kaunas Technical College ${ }^{2}$, Kaunas, Lithuania
}

\begin{abstract}
The aim of the research is to ascertain and compare the attitude of the students, enrolled in the Lithuanian Law University, Police Faculty in the years 2002 and 2003, to their state of health and means of improving it.

The article deals with the questionnaire data about the subjective knowledge on the state of health, means of its control and management of the students enrolled in the Lithuanian Law University, Police Faculty in the years 2002 and 2003. The first year students were questioned anonymously (in $2002-219$ students, in
\end{abstract}


2003 - 127 students). The questionnaire's validity was tested. A pilot research was done, the stability of the questionnaire was established. The data about the students' attitude to their physical state of health and peculiarities of its management are presented in the article. 16555 answers to 18 questions were analysed and grouped. The answers and data (according to gender features) (141 females and 205 males) of the exercising (215) and non-exercising (131) students were compared.

Majority of the questioned students take care of their health (90.2\%). In comparison with 2002, the subjective state of health of the major part of the students enrolled in the university in 2003 is satisfactory $(p<0.05)$, of the minor part of students is good $(p<0.01)$. Most of the males $(p<0.05)$ compared to females, as well as exercising students ( $<$ 0.001) compared to non-exercising students, rated their state of health as good. Large majority of students expressed their wish to get information about various aspects of improving their physical health on TV (47.4\%), fewer students (37.3\%) would like to get information at the lectures, in newspapers $(22.3 \%)$ or from specialist's counselling $(25.1 \%)$. The minor part of the respondents $(45.7 \%$, $\mathrm{p}<0.05)$ alleged that they acquired knowledge about impact of physical education to their health in secondary school. Majority of the respondents $(60.9 \%, p<0.001)$ stated that they had been and are taking interest in information about the impact of physical exercises to their health. $46.9 \%(p<0.001)$ alleged that their access to such kind of information sources is sufficient, $20 \%$ - insufficient and $30.2 \%$ of the students had no interest in it.

Only $21.1 \%(p<0.001)$ of the respondents control their state of health according to their pulse rate. $68.8 \%$ of the students do not do it, 9.2\% ( $\mathrm{p}<0.001$ ) do not know how to do it. More first year students $(p<0.01)$ enrolled in the university in the year 2003 than in 2002 have no knowledge about the methods of taking pulse rate. The students of the Lithuanian Law University, Police Faculty have the right conception about the means of improving their physical health. However, comparatively small part of the respondents has information about the basic methods of health state control and management of physical activity. This part of students has a tendency to decrease.

Keywords: physical fitness, knowledge about physiological indicators, control of the body state, aspects of management of physical activity process.

Gauta $2005 \mathrm{~m}$. vasario $1 \mathrm{~d}$.

Received on February 1, 2005

Priimta 2005 m. gegužès 18 d.

Accepted on May 18, 2005

Algirdas Muliarčikas

Mykolo Romerio universitetas

(Mykolas Romeris University)

V. Putvinskio g. 70, LT-44211 Kaunas

Lietuva (Lithuania)

Tel +370 37303653

E-mail a.muliarcikas@1tukf.1t 